\title{
Deep-sea food bonanzas: early Cenozoic whale-fall communities resemble wood-fall rather than seep communities
}

\author{
Steffen Kiel ${ }^{1,2, *}$ and James L. Goedert ${ }^{3}$
}

${ }^{1}$ School of Earth and Environment, University of Leeds, Leeds LS2 9fT, UK

${ }^{2}$ Department of Paleobiology, Smithsonian Natural History Museum, Washington, DC 20013-7012, USA

${ }^{3}$ Burke Museum, University of Washington, Seattle, WA 98195-3010, USA

\begin{abstract}
The evolutionary history of invertebrate communities utilizing whale carcasses and sunken wood in the deep-sea is explored using fossil evidence. Compared to modern whale-fall communities, the Eo-Oligocene examples lack those vent-type taxa that most heavily rely on sulphide produced by anaerobic breakdown of bone lipids, but are very similar in their trophic structure to contemporaneous wood-falls. This sheds doubt on the hypothesis that whale-falls were evolutionary stepping stones for taxa that now inhabit hydrothermal vents and seeps. We suggest that the whale-fall communities reported here represent a new ecologic stage among whale-falls, which we have coined the 'chemosymbiotic opportunist stage' and that the 'sulphophilic stage' of modern whale-falls developed during the Early Miocene, resulting from a significant increase in both body size and/or oil content of bones among cetaceans during this time.
\end{abstract}

Keywords: Mollusca; deep-sea; ecology; evolution; fossil record; whale-fall; wood-fall

\section{INTRODUCTION}

Whale carcasses and sunken wood in the deep-sea harbour extraordinary invertebrate communities resembling those found at hydrothermal vents and cold seeps (Smith \& Baco 2003). Recent discoveries of unusual whale-specialists with symbiotic relationships previously unknown from the animal kingdom have highlighted our poor knowledge of deep-sea environments (Rouse et al. 2004; Glover et al. 2005). Even less well understood is the fossil and evolutionary history of these environments. Based on shared taxa Baco et al. (1999) and Distel et al. (2000) hypothesized that whale- and wood-falls served as evolutionary 'stepping stones' for vent and seep animals. Whereas Smith (in press) suggested that whale-fall communities relying on the anaerobic breakdown of bone lipids have been functionally similar for the last $30 \mathrm{Myr}$, Squires et al. (1991) indicated that, at least in the Northeast Pacific, whale carcasses large enough to sustain many chemosynthetic animals were not available before the Late Miocene (approx. 11 Myr ago).

Cenozoic deep-water sediments in Washington State, USA, have produced fossil wood- and whale-fall communities dating from the time of origin of the modern suborders of ocean-going whales and they occur in close geographic and stratigraphic proximity to cold seeps (Goedert et al. 1995; Kiel \& Goedert in press). This area provides an excellent opportunity to study potential migrations into and between these environments at geologic time scales and to test current hypotheses regarding the origins of the deep-sea chemosynthetic fauna. Here we analyse 34 Eocene to Miocene whale- and wood-fall communities from these sediments, compare

*Author for correspondence (kiels@si.edu). them to other fossil examples of these environments from this time period, and present our conclusions on the origin and evolution of whale-fall communities.

\section{MATERIAL AND METHODS}

The studied sediments of the Lincoln Creek, Makah and Pysht Formations (figure 1) belong to the Coast Range terrane, which is part of the Cascadian accretionary wedge. These sediments were deposited in bathyal depths and for the last $35 \mathrm{Myr}$ have been accreted to the accretionary wedge and uplifted by the ongoing subduction of the Juan de Fuca plate under the North American continent (Rau 1966; Snavely et al. 1978; Snavely et al. 1980; Batt et al. 2001; Stewart \& Brandon 2004). These thick sediment sequences are generally fossilpoor, monotonous, thick-bedded silt- and mudstones, but contain also calcareous concretions with whale bones and wood associated with fossil mollusc assemblages that resemble those of modern whale- and wood-falls. The wood is heavily bored or fragmented by teredinids or xylophagains (shipworms) and all associated molluscs were found within a few millimetres of wood particles. The whale bones are commonly corroded in the upper part of the concretion but wellpreserved in the lower part, indicating that they were exposed for some time on the seafloor (Goedert et al. 1995) and accessible to bone-degrading organisms. In addition to material collected by us, four whale-bearing concretions with associated fauna were located in the collection of Douglas R. Emlong, now housed in the Smithsonian Natural History Museum (USNM). Invertebrates associated with USNM specimens were mechanically removed from those concretions. Wood-bearing concretions were mechanically broken in the field and laboratory to recover the associated invertebrate fossils. Self-collected whale-bearing concretions were checked in the field for diagnostic bones and, when these were present, 
(a)

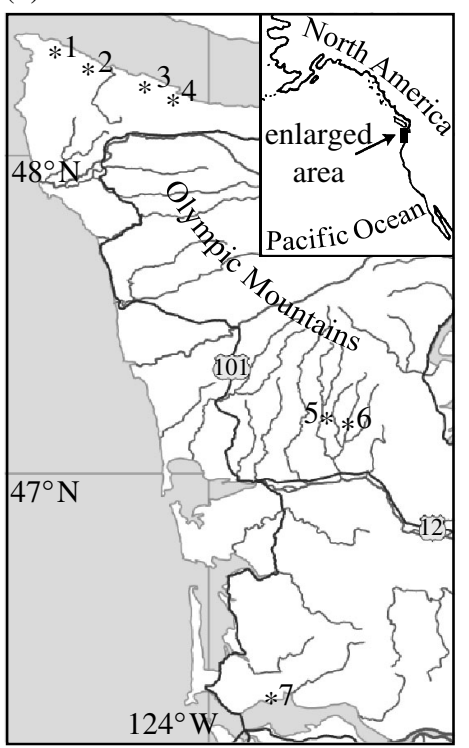

(b)

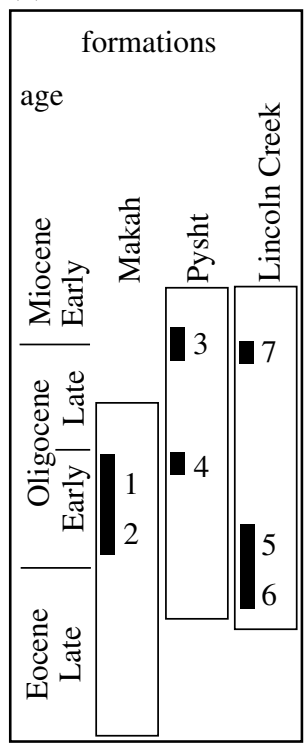

Figure 1. Geographic and stratigraphic occurrence of woodand whale-falls in the study area. (a) Sketch-map of western Washington state, fossil sites are indicated by asterisks; 1, Shipwreck Point; 2, Sekiu River; 3, Merrick's Bay; 4, Murdock Creek; 5, Canyon River; 6, Satsop River; 7, Knappton. (b) Stratigraphic framework, numbers correspond to the localities indicated on the map.

most of the associated molluscs were recovered during the preparation of the bones in the laboratory. When diagnostic bones were absent, the concretions were broken up entirely to recover associated invertebrates. The molluscan fossils were determined to the lowest taxonomic level possible and their ecology was inferred from extant relatives (cf. Kiel \& Goedert in press).

Only wood- and whale-fall sites with at least one key taxon characteristic for such localized biogenic substrates are analysed and discussed here, although this approach bears the risk that we exclude wood- and whale-fall communities that were ecologically different from the modern ones (cf. Kiel \& Goedert in press). Key taxa are the acmaeid limpet Pectinodonta and the bathymodiolin mussel Idas n. sp. Extant Pectinodonta occurs exclusively at wood-falls (Marshall 1985; Lindberg \& Hedegaard 1996) and Recent Idas is known from wood- and whale-falls, and cold-seeps (Jones et al. 2005). However, fossil cold-seep carbonates are very distinctive geologic features that cannot be mistaken for wood-fall concretions. We utilize the same approach for whale-fall sites, with mytilids being the key taxa. Wood-fall material is deposited in the USNM and in the Los Angeles County Museum (LACMIP); newly collected whale-fall material is deposited in the Burke Museum, University of Washington (UWBM). The complete list of sites and species is available online. Species indicated as new will be described in a forthcoming taxonomic paper. Statistical analyses were carried out using EstimateS v. 7.5 (Colwell 2005) for species accumulation curves and richness estimates and with PAST v. 1.37 (Hammer et al. 2001) for cluster analyses.

\section{RESULTS}

Twenty-nine molluscan taxa (excluding teredinid or xylophaganiid shipworms) were identified from 28 wood-fall communities (figure 2). All had a benthic

mode of life; hence colonization of the wood began after it sank to the deep-sea floor. Taxa (number of sites in parentheses) that most likely grazed upon xylophagous microbes and fungi are Pectinodonta palaeoxylodia (14), the polyplacophoran Leptochiton (5), the gastropods Provanna (2), Trenchia (1), Hyalogyrina n. sp. (1) and a cocculinid (1). Taxa that relied partly or entirely on chemoautotrophic endosymbionts include the mytilid Idas n. sp. (26), the thyasirid Thyasira n. sp. (4) and the lucinid Lucinoma acutilineatum (1). Predatory, scavenging or parasitic taxa include the buccinid gastropods Colus (10), naticids (4), Cylichna (2), Admete viridula (2), unidentified turrids and muricids (2), Turbonilla (1) and the scaphopod Dentalium laneensis (1). Detritus-feeding taxa with uncertain relation to the wood include three nuculanid bivalves (Nuculana cf. grasslei, Nuculana n. sp., and an unidentified Nuculana, six sites), a pectinid bivalve (commonly known in this area as 'mud pecten', 4 sites), tellinid (2), propeamussiid (1) and limopsid (1) bivalves and a solariellid gastropod (1).

The six whale-fall communities were found associated with archaic mysticete and other archaic whales; none of the whales exceeding $6 \mathrm{~m}$ in length. Among them is the oldest known whale-fall community consisting of an unidentified mytilid and a buccinid with a probable mysticete from the latest Eocene (approx. 34-35 Myr ago) part of the Lincoln Creek Formation. Eleven taxa were identified (number of sites in parentheses) from the other five whale-falls, these being mainly chemosymbiotic bivalves, predatory gastropods and a few detritus-feeders; epifaunal grazers are lacking. Chemosymbiotic taxa include Idas n. sp. (5), a new Thyasira species (1), Idasola? sp. (1), Conchocele bisecta (1) and Lucinoma (1). The new Thyasira species has previously been reported from Oligocene whale-falls as Thyasira peruviana? Olsson (Goedert et al. 1995), but examination of T. peruviana specimens from Olsson's collection at the USNM showed that these are different species. Predators include naticids (2), Scaphander (1) and an unidentified neogastropod (1); detritus-feeders are two Nuculana species (3) and one pectinid (1). The identity of Idasola? sp. is not yet fully resolved; Idasola was shown to be a synonym of Idas (Warén 1991), and Amano \& Little (2005) recently suggested that this species might be identical with Adipicola chikubetsuensis from Miocene whale-fall in Japan. The presently available material of Idasola? sp. is insufficient to resolve this problem.

The identified species are a representative sample of the regional species pool of fossilizable whale- and wood-fall colonizers, and show that Eocene-Oligocene whale-fall communities were less diverse and trophically less complex than those at contemporaneous wood-falls. The 34 sites do not show higher numbers of shared species within any one of the three formations (figure 3), indicating that the three rock units share a regional species pool of whale- and wood colonizers. The species accumulation curve for wood-falls shows an increment of 0.5 species between the penultimate and the last of our 28 sites (figure 4). The estimated species richness extrapolated from the accumulation curve is between 35 species (bootstrap estimator) and 50 species (secondorder Jackknife estimator). When the nine additional taxa described earlier (Kiel \& Goedert in press) are included, the increment between the penultimate and the last site is 0.75 species and the richness estimates are between 46 and 


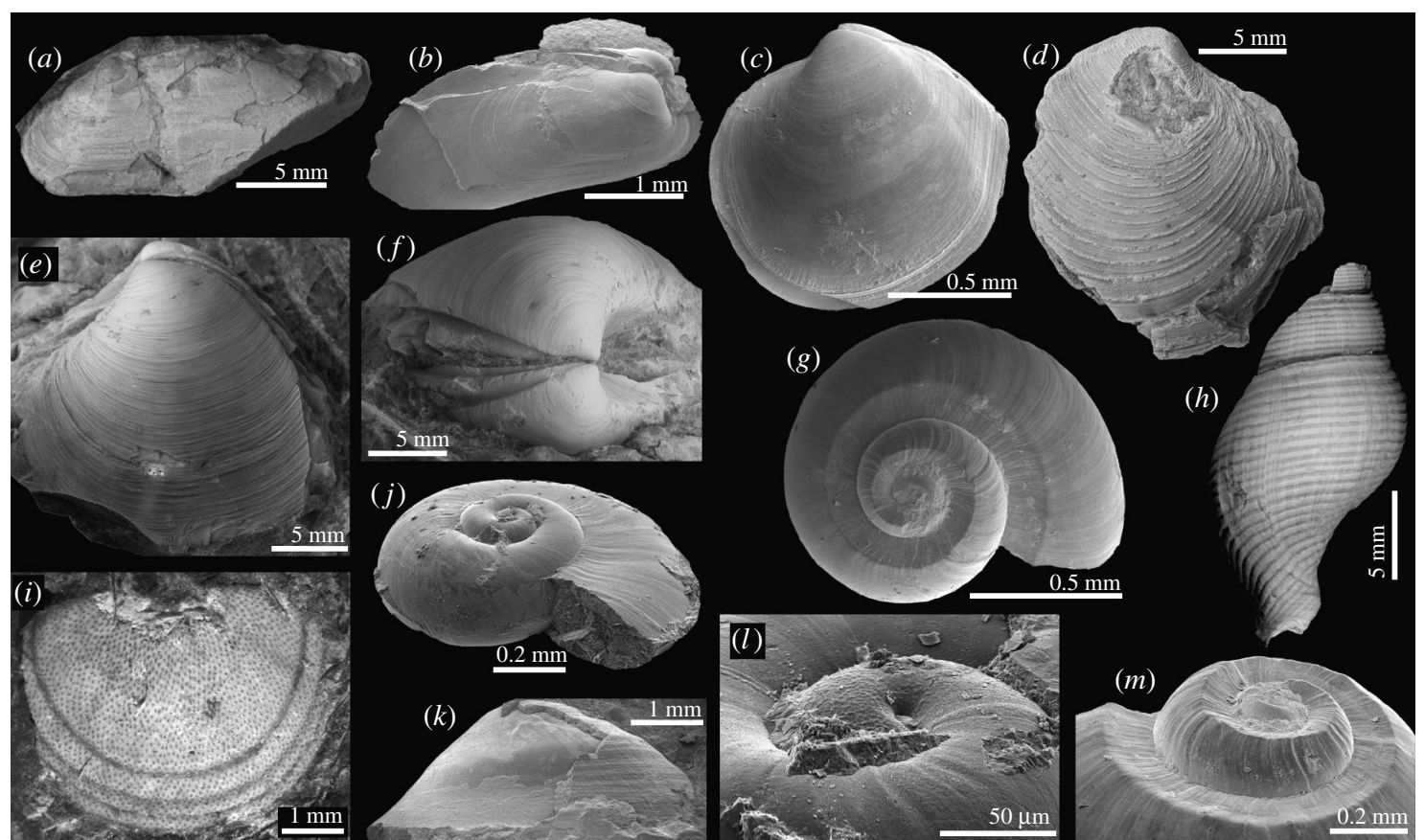

Figure 2. Examples of molluscs from fossil whale- and wood-falls in Washington. (a) 'Idasola'? sp. from a whale-fall (loc. 2F, USNM 531399). (b) Idas n. sp. from a wood-fall (loc. 4F, USNM 531400). (c) Juvenile Conchocele bisecta from a whale-fall (loc. 4M, USNM 531401). (d) Lucinoma sp. from a whale-fall (loc. 2E, USNM 531402). (e, f) Thyasira n. sp. from a woodfall (loc. 4J, LACMIP 13370). ( $g, m$ ) Trenchia sp. from a wood-fall (loc. 4A, USNM 531403). (h) Colus sp. from a wood-fall (loc. 4A, USNM 531404). (i) Leptochiton sp. from a wood-fall (loc. 5C, USNM 531405). ( $j$ ) Hyalogyrina $\mathrm{n}$. sp. from a wood-fall (loc. 3A, USNM 531406). (k) cocculiniform limpet from a wood-fall (loc. 4E, USNM 531407). (l) Hyalogyrina n. sp. same specimen as $(j)$, close-up showing wrinkles on embryonic shell.

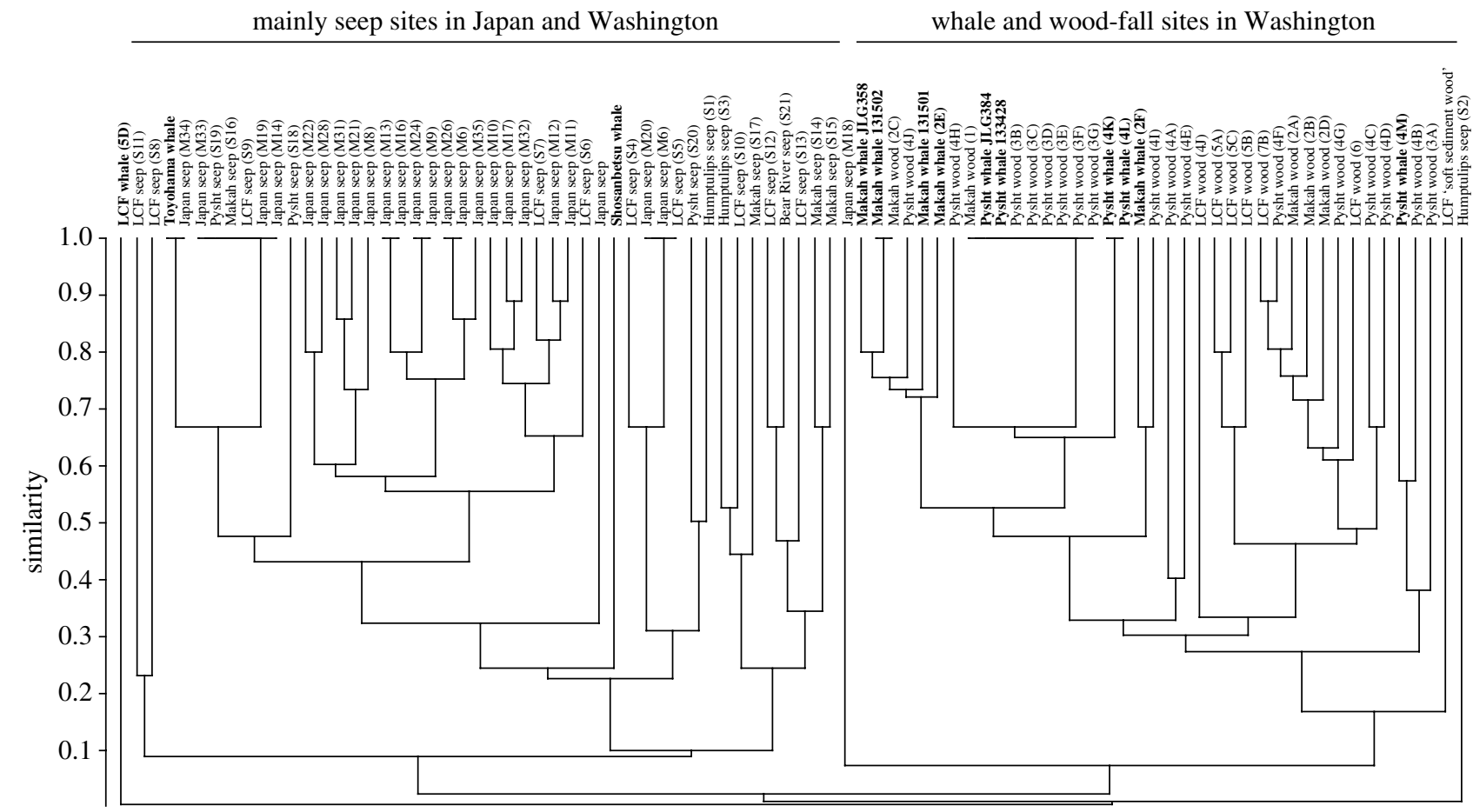

Figure 3. Faunal similarities of 88 Eocene to Miocene whale-fall, wood-fall and cold-seep sites in Washington and Japan. Numbers in brackets refer to locality numbers in figure 1, with added letters when more than one site was found at that locality; numbers with preceeding ' $S$ ' refer to Washington seep sites listed in the data table that is available online; numbers with preceeding ' $M$ ' refer to the locality numbers of Majima et al. (2005) for Japanese seeps; whale-fall sites in bold; LCF, Lincoln Creek Formation.

72 species. This appears to suggest that our sample does not yet represent the entire species pool of wood-fall colonizers. However, using only those species that have an intimate relation to the wood (e.g. those species with evident in situ food source, cf. Kiel \& Goedert in press), the species accumulation curve has almost levelled off after 28 sites (figure 4). This suggests that an increasing sample size will largely add vagrant and 'accidental' species, but the regional pool of species with an intimate relation to the wood is largely known. The accumulation curve of 


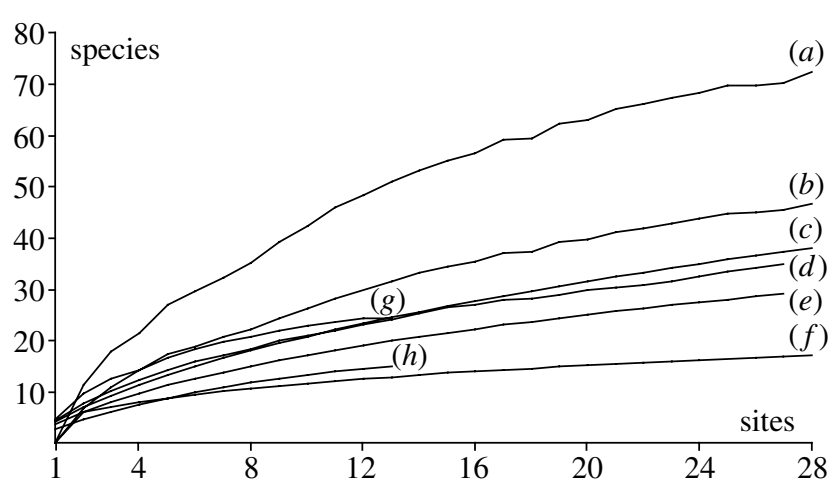

Figure 4. Species accumulation curves and richness estimates for whale- and wood-fall species in Washington. (a) Jack 2 estimator of wood-fall species including the 'soft sediment' site of Kiel \& Goedert (in press). (b) Bootstrap estimator of wood-fall species including the 'soft sediment' site. (c) Accumulation curve of wood-fall species including the soft sediment site. (d) Bootstrap estimator for wood-fall species only from sites reported herein. (e) Accumulation curve of wood-fall species only from sites reported herein. $(f)$ Accumulation curve of wood-fall species with an intimate relation to the wood. ( $g$ ) Jack 2 estimator for whale-fall species. (h) Accumulation curve of whale-fall species.

whale-fall species (including sites with mytilids described by Goedert et al. 1995) still shows higher increments than the wood-fall curve. However, even the most optimistic richness estimator (second-order Jackknife) predicts just over 24 whale-fall species, whereas 38 taxa are known from wood-falls.

Based on species shared between modern seeps and whale-falls, Amano \& Little (2005) expected that fossil seep-species have utilized contemporaneous whale-falls as well, whereas Smith et al. (1989) used the same argument to predict a whale-to-seep/vent adaptation. The taxa described here represent the earliest known colonizers of the newly available 'whale-fall' habitat in the late Eocene and Oligocene; none were previously endemic to contemporaneous seeps. Rather, species shared between the two habitats are infaunal species that also occur elsewhere in the sulphide-rich sediments of western Washington (table 1). Two whale-fall species were previously known only from stratigraphically older wood-falls. The Oligocene Idasola? sp. has not been reported from any other environment. Thus, the first whale-fall endemic species had evolved by the Mid-Oligocene.

To further assess the relationships between fossil whalefall, wood-fall and seep communities through geologic time, we compared faunal similarities between Late Eocene and Miocene examples of these environments from Washington and Japan. Japan is included because it has a rich record of fossiliferous seeps from this time interval (Majima et al. 2005) as well as the only fossil whale-fall communities known from outside Washington (Hachiya 1992; Amano \& Little 2005). Seep data from Washington are compiled from the literature (Goedert \& Squires 1990; Peckmann et al. 2002; Goedert et al. 2003; and references therein) with additional taxa and systematic revisions of Kiel (2006). Data on seep communities in Japan are mainly from the compilation of Majima et al. (2005) and additional sources of non-chemosymbiotic seep taxa (Kanno et al. 1989; Kanie \& Sakai 1997;
Table 1. Taxa from Eocene and Oligocene whale-falls in Washington (including taxa described by Goedert et al. (1995) and the habitats from which they had previously been described.

\begin{tabular}{ll} 
taxon & other habitats \\
\hline Idasola? sp. & unknown \\
Mytilid & unknown \\
Conchocele bisecta & seep?, reducing sediment \\
Lucinoma $\mathrm{sp}$. & seep, reducing sediment \\
Thyasira $\mathrm{sp}$. & seep, reducing sediment \\
Naticid? & seep, wood, background \\
Buccinid & seep?, wood, background \\
Nuculana $\mathrm{n} . \mathrm{sp}$. & seep, wood \\
Idas n. $\mathrm{sp}$. & wood \\
Thyasira $\mathrm{n} . \mathrm{sp}$. & wood \\
Nuculana $\mathrm{sp}$. & wood, background \\
Pectinid & wood, background \\
Scaphander $\mathrm{sp}$. & background \\
Brachiopod & background \\
\hline
\end{tabular}

Amano et al. 2001; Amano 2003). As Majima et al. (2005, p. 89) did not evaluate generic assignments of various taxa assigned to the Vesicomyidae, we treated the genera and subgenera Adulomya, Akebiconcha, Ectenagena and Hubertschenkia as synonyms of Calyptogena (cf. Coan et al. 2000), to maintain taxonomic consistency between the sites in Japan and Washington. Also included in the analysis are those five whale-falls described by Goedert et al. (1995) that contain mytilids. The two late Oligocene whale-fall assemblages described by Nesbitt (2005) from the upper part of the Pysht Formation are not included here because all reported species are rather common in these sediments (Nesbitt 2005; J. L. Goedert 1990, personal observations), thus providing little evidence for trophic relationships between them and the whale bones. The communities were compared using genus and family level identifications; species level comparison was not feasible due to the limited number of species-level identifications, and due to the difficulties of distinguishing fossil species among bivalve groups like vesicomyids that are known for their cryptic species (Goffredi et al. 2003). Faunal similarities were calculated pair-wise and using the Dice, Jaccard and Raup-Crick indices, all of which delivered very similar results.

The cluster diagram (figure 3) shows two interesting patterns; first, there are two distinct clusters: one composed of seep communities in Washington and Japan and the two Miocene whale-falls in Japan, the other of whale- and wood-fall communities in Washington. This indicates that the Oligocene whale-fall communities were more similar to contemporaneous wood-fall communities than to the Miocene whale-falls. The position of the two Miocene whale-falls within the seep cluster and outside the Washington whale- and wood-fall cluster is robust, even when we increased the number of shared taxa between the whale- and wood-falls by synonymizing the records of Idas, Idasola and Adipicola (cf. Warén 1991). Second, the whale-falls within the Washington whale- and wood-fall cluster are widespread rather than forming a distinct sub-cluster, suggesting that they were not (yet) ecologically distinct. 


\section{DISCUSSION}

The whale-fall communities described herein are the earliest known to date and appear synchronous with the earliest dispersal of Mysticeti, large filter-feeding whales (Fordyce \& de Muizon 2001). But contrary to earlier assumptions (Baco et al. 1999; Smith in press) our data suggest that these earliest whale-fall communities were not functionally similar to modern ones. The first pattern in our cluster diagram that merits explanation is the clear distinction between Oligocene and more modern whale-fall communities. Whereas modern whale-falls in the sulphophilic stage (cf. Smith \& Baco 2003) harbour a substantial diversity of semi-infaunal vesicomyids that are closely related to those living at vents and seeps (Baco et al. 1999), vesicomyids are absent from the Eocene and Oligocene whale-falls, despite their abundance in contemporaneous seep carbonates in the same formations. Instead, we find infaunal thyasirids and lucinids in the Oligocene whalefall communities-the same species also occur elsewhere in the sulphide-enriched sediments and at wood-falls of the Makah and Pysht formations. Modern whale-falls also harbour a large number of epifaunal grazers that feed on sulphur-oxidizing bacteria on the surfaces of bones (Smith \& Baco 2003). Such epifaunal microbe-grazers are absent from the Eocene and Oligocene whale-falls. Bacterial degradation of oil in the whale bones is the main source of sulphide at modern whale-falls after the soft tissue has disappeared (Smith \& Baco 2003). Thus the absence of those taxa that most heavily rely on sulphide for nutrition (vesicomyids and epifaunal microbe-grazers) from all known Eocene and Oligocene whale-fall communities suggests that these bones provided too little oil to sustain these animals.

Instead, species that relied on sulphur oxidizing symbionts (thyasirids, lucinids and to some extent, mytilids) may have used two alternative sources of sulphide. The sediment below and surrounding the decaying whale carcass becomes enriched in organic material (Naganuma et al. 1996) and its degradation quickly exhausts the available oxygen. Anaerobic breakdown of the organic matter then takes over, resulting in the release of considerable quantities of sulphide (Allison 1988). In addition, the redox zone in the sediment below the whale carcass is likely to rise significantly as the overlying carrion cuts off the oxygen supply derived from seawater. Sulphide would then be stable under these anoxic conditions. In this respect the Oligocene whale-falls were functionally similar to contemporaneous wood-falls where sulphide was probably enriched in a very similar way, with faeces (mainly from xylophagains) rather than carrion causing the redox zone to rise and organic material to be broken down anaerobically (Kiel \& Goedert in press). This interpretation could explain the strong faunal similarities between the Oligocene whale- and wood-fall communities (figure 3).

In summary, the Eocene-Oligocene whale-falls lacked a 'sulphophilic stage' fuelled by anaerobic breakdown of bone lipids, but supported chemosymbiotic animals with sulphide resulting from processes that we would expect to find in the 'enrichment opportunist stage' of extant whalefalls (cf. Smith \& Baco 2003). This stage is today characterized by vast numbers of opportunistic polychaetes and crustaceans (Smith \& Baco 2003). Although crustaceans are generally present in Eocene to Miocene sediments in Washington (Schweitzer \& Feldman 1999), they have not been found associated with fossil whale-falls. To account for the differences between extant and Eo-Oligocene whale-fall communities, the fossil examples are here interpreted to represent an independent stage in whale-fall successions. This 'chemosymbiotic opportunist stage' is characterized by species from wood-falls and from the background fauna which are adapted to reducing environments and most likely took advantage of elevated sulphide levels in the sediments underneath and around the whale carcass, rather than from anaerobic breakdown of bone lipids. Additional taxa include small predatory gastropods and few detritus-feeders. In an evolutionary perspective, fossil evidence suggests that the sulphophilic stage of modern whale-falls evolved during Early Miocene time. An Early Miocene whale-fall in Japan has vesicomyid bivalves associated with it (Hachiya 1992), and Middle Miocene whale-falls have a modern, or 'sulphophilic' appearance with abundant microbe-grazers and vesicomyid bivalves (Amano \& Little 2005). This change suggests an increase in the amount of oil provided by whale bones during this time period. This may relate either to a relative increase in the oil content of whale bones or simply to an increase in the size of the bones (and whales). Whether the absence of limpets from the Miocene whale-falls is due to sampling issues (cf. Amano \& Little 2005) or relates to the oil content of the whale bones, too, remains to be tested by further fossil evidence. The utilization of putative bones lipids in Mesozoic marine reptile- and fish-falls and their role for the dispersal of vent and seep animals has been speculated upon (Martill et al. 1991), but evidence for associated chemosymbiotic taxa is lacking (Hogler 1994). However, a chemosymbiotic opportunist stage as outlined here for Eo-Oligocene whales could have existed at Mesozoic reptile-falls.

The hypothesis that whale-falls served as evolutionary stepping stones in the colonization of vents and seeps was partly based on the roughly synchronous molecular divergence date estimates for the bivalve family Vesicomyidae and the origin of large whales (Baco et al. 1999). The absence of vesicomyids at the earliest whale-falls (28-35 Myr ago) challenges the molecular evidence for this hypothesis, especially as vesicomyids were present at cold-seeps in the same formations. Thus, not only have vesicomyids a much longer history than predicted by molecular estimates (Little \& Vrijenhoek 2003), these estimates also do not match the first known occurrence of vesicomyids at whale-falls (Early Miocene, ca $20 \mathrm{Myr}$ ago). Bathymodiolin mussels were also considered in the stepping-stone hypothesis (Distel et al. 2000). Within this group molecular age estimates have a rather broad range from 22 to $94 \mathrm{Myr}$ ago (Little \& Vrijenhoek 2003; Jones et al. 2005). The oldest bathymodiolins at fossil seeps, whale- and wood-falls plot in the younger half of this range (30-38 Myr ago). Bathymodiolus occurs at Middle Eocene seeps (Kiel 2006) and Idas is here reported from Late Eocene and Oligocene wood- and whale-falls. The bathymodiolins occur earlier at seeps than at wood- and whalefalls contrary to the predicted pattern (Distel et al. 2000). However, these records are so close in time that it is 
currently impossible to either reject or confirm the stepping-stone hypothesis for bathymodiolins based on palaeontological grounds. Nevertheless, the observed pattern follows the geologic history of these environments, with seeps being older than wood and wood being older than whales.

We thank D. J. Bohaska, W. E. Coventon, C. T. S. Little, S. Nissen, C. R. Smith and M. D. Uhen for help and stimulating discussion, and two anonymous reviewers for their suggestions. S.K. was supported by a Walcott fellowship (Smithsonian Institution) and by a EU Marie-Curie fellowship. Field work was generously supported by D. Starr and H. Ferguson, Seattle and the Burke Museum.

\section{REFERENCES}

Allison, P. A. 1988 The role of anoxia in the decay and mineralization of proteinaceous macro-fossils. Paleobiology 14, 139-154.

Amano, K. 2003 Predatory gastropod drill holes in Upper Miocene cold seep bivalves, Hokkaido, Japan. Veliger 46, 90-96.

Amano, K. \& Little, C. T. S. 2005 Miocene whale-fall community from Hokkaido, northern Japan. Palaeogeogr. Palaeoclimat. Palaeoecol. 215, 345-356. (doi:10.1016/ j.palaeo.2004.10.003)

Amano, K., Hamuro, T., Hamuro, M. \& Fujii, S. 2001 The oldest vesicomyid bivalves from the Japan sea borderland. Venus 60, 189-198.

Baco, A. R., Smith, C. R., Peek, A. S., Roderick, G. K. \& Vrijenhoek, R. C. 1999 The phylogenetic relationships of whale-fall vesicomyid clams based on mitochondrial COI DNA sequences. Mar. Ecol. Prog. Ser. 182, 137-147.

Batt, G. E., Brandon, M. T., Farley, K. A. \& Roden-Tice, M. 2001 Tectonic synthesis of the Olympic mountains segment of the Cascadia wedge, using two-dimensional thermal and kinematic modeling of thermochronological ages. F. Geophys. Res. 106, 26 731-26 746. (doi:10.1029/ 2001JB000288)

Coan, E. V., Scott, P. V. \& Bernard, F. R. 2000 Bivalve seashells of western North America. Santa Barbara, CA: Santa Barbara Museum of Natural History.

Colwell, R. K. 2005 EstimateS: statistical estimation of species richness and shared species from samples. Version 7.5. User's guide and application. http://viceroy.eeb. uconn.edu/estimates.

Distel, D. L., Baco, A. R., Chuang, E., Morrill, W., Cavanaugh, C. \& Smith, C. R. 2000 Do mussels take wooden steps to deep-sea vents? Nature 403, 725-726. (doi:10.1038/35001667)

Fordyce, R. E. \& de Muizon, C. 2001 Evolutionary history of cetaceans: a review. In Secondary adaptation of tetrapods to life in water (ed. J.-M. Mazin \& V. de Buffrénil), pp. 169-233. München, Germany: Dr. Friedrich Pfeil.

Glover, A. G., Källström, B., Smith, C. R. \& Dahlgren, T. G. 2005 World-wide whale worms? A new species of Osedax from the shallow north Atlantic. Proc. $R$. Soc. B 272, 2587-2592. (doi:10.1098/rspb.2005.3275)

Goedert, J. L. \& Squires, R. L. 1990 Eocene deep-sea communities in localized limestones formed by subduction-related methane seeps, southwestern Washington. Geology 18, 1182-1185. (doi:10.1130/0091-7613(1990) $018<1182$ :EDSCIL $>2.3$. CO;2)

Goedert, J. L., Squires, R. L. \& Barnes, L. G. 1995 Paleoecology of whale-fall habitats from deep-water Oligocene rocks, Olympic Peninsula, Washington State. Palaeogeogr. Palaeoclimat. Palaeoecol. 118, 151-158. (doi:10.1016/0031-0182(94)00139-Y)
Goedert, J. L., Thiel, V., Schmale, O., Rau, W. W., Michaelis, W. \& Peckmann, J. 2003 The late Eocene 'Whiskey Creek' methane-seep deposit (western Washington State) Part I: geology, palaeontology, and molecular geobiology. Facies $48,223-240$.

Goffredi, S. K., Hurtado, L. A., Hallam, S. J. \& Vrijenhoek, R. C. 2003 Evolutionary relationships of deep-sea vent and cold seep clams (Mollusca: Vesicomyidae) of the "pacificallepta" species complex. Mar. Biol. 142, 311-320.

Hachiya, K. 1992 A unique community in the reduced environment found from the Morozaki group. Kaseki no Tomo (Publication of the Tokai Fossil Society) 39, 37-41.

Hammer, Ø., Harper, D. A. T. \& Ryan, P. D. 2001 PAST: palaeontological statistics software package for education and data analysis. Palaeontologia Electronica 4.

Hogler, J. 1994 Speculations on the role of marine reptile deadfalls in Mesozoic deep-sea paleoecology. Palaios 9, $42-47$.

Jones, W. J., Won, Y.-J., Maas, P. A. Y., Smith, P. J., Lutz, R. A. \& Vrijenhoek, R. C. 2005 Evolution of habitat use by deep-sea mussels. Mar. Biol. 148, 841-851.

Kanie, Y. \& Sakai, T. 1997 Chemsynthetic thraciid bivalve Nipponothracia, gen. nov. from the Lower Cretaceous and Middle Miocene mudstones in Japan. Venus 56, 205-220.

Kanno, S., Amano, K. \& Ban, H. 1989 Calyptogena (Calyptogena) pacifica Dall (Bivalvia) from the Neogene system in the Joetsu district, Niigata prefecture. Trans. Proc. Palaeont. Soc. Fapan, New Ser. 153, 25-35.

Kiel, S. 2006 New records and species of mollusks from Tertiary cold-seep carbonates in Washington state, USA. 7. Paleontol. 80, 121-137. (doi:10.1666/0022-3360(2006) 080[0121:NRASOM]2.0.CO;2)

Kiel, S. \& Goedert, J. L. In press. A wood-fall association from Late Eocene deep-water sediments of Washington State, USA. Palaios.

Lindberg, D. R. \& Hedegaard, C. 1996 A deep water patellogastropod from Oligocene water-logged wood of Washington State, USA (Acmaeoidea: Pectinodonta). f. Moll. Stud. 62, 299-314.

Little, C. T. S. \& Vrijenhoek, R. C. 2003 Are hydrothermal vent animals living fossils? Trends Ecol. Evol. 18, 582-588. (doi:10.1016/j.tree.2003.08.009)

Majima, R., Nobuhara, T. \& Kitazaki, T. 2005 Review of fossil chemosynthetic assemblages in Japan. Palaeogeogr. Palaeoclimat. Palaeoecol. 227, 86-123. (doi:10.1016/ j.palaeo.2005.04.028)

Marshall, B. A. 1985 Recent and Tertiary deep-sea limpets of the genus Pectinodonta Dall (Mollusca: Gastropoda) from New Zealand and New South Wales. $N Z$ F. Zool. 12, 273-282.

Martill, D. M., Cruickshank, A. R. I. \& Taylor, M. A. 1991 Dispersal via whale bones. Nature 351, 193. (doi:10.1038/ 351193a0)

Naganuma, T., Wada, H. \& Fujikoka, K. 1996 Biological community and sediment fatty acids associated with the deep-sea whale skeleton at the Torishima Seamount. f. Oceanogr. 52, 1-15. (doi:10.1007/BF02236529)

Nesbitt, E. A. 2005 A novel trophic relationship between cassid gastropods and mysticete whale carcasses. Lethaia 38, 17-25.

Peckmann, J., Goedert, J. L., Thiel, V., Michaelis, W. \& Reitner, J. 2002 A comprehensive approach to the study of methane-seep deposits from the Lincoln Creek Formation, western Washington State, USA. Sedimentology 49, 855-873. (doi:10.1046/j.1365-3091.2002.00474.x)

Rau, W. W. 1966 Stratigraphy and Foraminifera of the Satsop River area, southern Olympic Peninsula, Washington. State of Washington Div. Mines Geol. Bull. 53, 1-66. 
Rouse, G. W., Goffredi, S. K. \& Vrijenhoek, R. C. 2004 Osedax: bone-eating marine worms with dwarf males. Science 305, 668-671. (doi:10.1126/science.1098650)

Schweitzer, C. E. \& Feldman, R. A. 1999 Fossil decapod crustaceans of the Pysht Formation (late Oligocene to early Miocene) and Quimper Sandstone (late Eocene), Olympic Peninsula, Washington. Ann. Carnegie Mus. 68, 215-273.

Smith, C. R. \& Baco, A. R. 2003 Ecology of whale falls at the deep-sea floor. Oceanogr. Mar. Biol. 41, 311-354.

Smith, C. R., Kukert, H., Wheatcroft, R. A., Jumars, P. A. \& Deming, J. W. 1989 Vent fauna on whale remains. Nature 341, 27-28. (doi:10.1038/341027a0)

Smith, C. R. In press. Bigger is better: the role of whales as detritus in marine ecosystems. In Whales, whaling and marine ecosystems (ed. J. Estes), Berkeley, CA: University of California Press.
Snavely, P. D. J., Niem, A. R., Pearl, J. E. \& Rau, W. W. 1978 Twin river group (Upper Eocene to Lower Miocene)defined to include the Hoko River, Makah, and Pysht Formations. US Geol. Surv. Prof. Pap. 1162, 1-28.

Snavely, P. D. J., Niem, A. R., MacLeod, N. S., Pearl, J. E. \& Rau, W. W. 1980 Makah Formation-a deep-marginalbasin sequence of late Eocene and Oligocene age in the northwerstern Olympic Peninsula, Washington. US Geol. Surv. Prof. Pap. 1162, 1-28.

Squires, R. L., Goedert, J. L. \& Barnes, L. G. 1991 Whale carcasses. Nature 349, 574. (doi:10.1038/349574a0)

Stewart, R. J. \& Brandon, M. T. 2004 Detrital-zircon fissiontrack ages for the "Hoh Formation": implications for late Cenozoic evolution of the Cascadia subduction wedge. GSA Bull. 116, 60-75.

Warén, A. $1991 \mathrm{New}$ and little known mollusca from Iceland and Scandinavia. Sarsia 76, 53-124. 


\section{NOTICE OF CORRECTION}

Kiel, S. \& Goedert, J. L. 2006 Deep-sea food bonanzas: early Cenozoic whale-fall communities resemble wood-fall rather than seep communities. Proc. R. Soc. B 273, 2625-2631. (doi:10.1098/rspb.2006.3620) is now presented in its correct form.

A detailed erratum will appear at the end of the volume. 